\title{
FROM CANDIDACY TO MEMBERSHIP
}

(Part I)

Hagen Lichtenberg*

\section{Contents}

I. Preliminary Remarks

II. The Development of Turkey-EC/EU Relations

1. The Association Agreement

2. The Customs Union

3. The Accession Partnership

III. The Legal Framework of Community Law for the Accession of New Member States

1. Association Agreement and Membership

2. The Treaty on European Union, Art. 49

3. The Copenhagen Criteria

4. The Accession Partnership

$I V$. The Adoption of the Acquis Communautaire by Turkey

$V$. Perspectives

\section{Preliminary Remarks}

Turkey's long march into the European Union has quite recently got new dynamic impulses. The adoption of the Accession Partnership by the Council of the European Union on March 2, 2001, and the presentation of Turkey's 'National Program for the Adoption of the Acquis" on March 26 are, according to Commissioner Guenther Verheugen, "a roadmap for Turkey to comply with the criteria for accession to the European Union" (Press Release IP/01/332 of 08 March).

Regarding my contribution to this volume of the Marmara Journal of European Studies this development has rather important effects.

* Prof. Dr. Jean Monnet Chair for European Community Law, University of Bremen and visiting professor at European Community Institute, Marmara University, Istanbul. 
Firstly, it does not seem appropriate any more, to discuss the substantive conditions for accession without reference to the relevant version of the Accession Partnership.

Secondly, the analysis of the accession procedure has consequently to focus on the conditions, laid down in the Accession Partnership document.

For these reasons, it seems useful to make this document known before discussing Conference.

In accordance with the editor of Marmara Journal of European Studies, I decided to split up the article and to use the space, which was accorded to it in this volume, to display the full text of the document on the Accession Partnership instead.

The next volume of the Marmara Journal of European Studies shall than include the article on the substantive and the procedural aspects of the prospective accession of Turkey to the EU.

\section{COUNCIL DECISION \\ on the principles, priorities, intermediate objectives and conditions contained in the Accession Partnership with the Republic of Turkey}

The Council of the European Union,

Having regard to the Treaty establishing the European Community,

Having regard to Council Regulation (EC) No .../2001 of ......... on assistance to Turkey in the framework of the pre-accession strategy, and in particular on the establishment of an Accession Partnership, 1 and in particular to Article 2 thereof,

Having regard to the proposal from the Commission,

Whereas:

(1) The Helsinki European Council stated: "Turkey is a candidate State destined to join the Union on the basis of the same criteria as applied 
to the other candidate States. Building on the existing European strategy, Turkey, like other candidate States, will benefit from a pre-accession strategy to stimulate and support its reforms." As a key feature of such a strategy, an Accession Partnership will be drawn up on the basis of previous European Council conclusions.

(2) Regulation (EC) No .../2001 provides that the Council is to decide,by a qualified majority and following a proposal from the Commission, on the principles, priorities, intermediate objectives and conditions contained in the individual Accession Partnership, as it will be submitted to Turkey, as well as on subsequent significant adjustments applicable to it.

(3) Community assistance is conditional on the fulfilment of essential elements, and in particular on progress towards fulfilment of theCopenhagen criteria. Where an essential element is lacking, the Council, acting by a qualified majority on a proposal from the Commission, may take appropriate steps with regard to any pre-accession assistance.

(4) The EC-Turkey Association Council decided that the implementation of the Accession Partnership for Turkey will be monitored by the Association Agreement bodies as appropriate.

(5) The Commission's 2000 regular report presented an objective analysis on Turkey's preparations for membership and identified a number of priority areas for further work.

(6) In order to prepare for membership, Turkey should prepare a national programme for the adoption of the acquis. This programme should set out a timetable for achieving the priorities and intermediate objectives established in the Accession Partnership,

\section{Has decided as follows:}

\section{$\underline{\text { Article } 1}$}

In accordance with Article 2 of Regulation (EC) No .../2001, the 
principles, priorities, intermediate objectives and conditions contained in the Accession Partnership for Turkey are set out in the Annex hereto, which forms an integral part of this Decision.

\section{$\underline{\text { Article } 2}$}

The implementation of the Accession Partnership shall be monitored in the Association Agreement bodies as appropriate and through the competent Council bodies to which the Commission shall report regularly.

\section{Article 3}

This Decision shall take effect on the third day following that of its in the Official Journal of the European Communities.

Done at Brussels,

For the Council The President

\section{$\underline{\text { Annex }}$}

Turkey: 2000 Accession Partnership

\section{Introduction}

The European Council in Helsinki (10-11 December 1999) welcomed the positive developments in Turkey as well its intention to continue its reform towards complying with the Copenhagen criteria. Turkey is a candidate State destined to join the Union on the basis of the same criteria as applied to the other candidate States.

At its meeting in Helsinki, the European Council decided that an Accession Partnership will be drawn up "on the basis of previous European Council conclusions". It shall contain priorities on which accession preparations must concentrate in the light of the political and economic criteria and the obligations of a Member State 
combined with a National Programme for the Adoption of the Acquis.

At its meeting in Luxembourg in December 1997, the European Council had decided that the Accession Partnership would be the key feature of the enhanced pre-accession strategy, mobilising all forms of assistance to the candidate countries within a single framework. In this manner, the EU targets its assistance towards the specific needs of each candidate so as to provide support for overcoming particular problems in view of accession.

In full compliance with this approach, the Commission proposed on 26 July 2000 a regulation for the establishment of a single framework for coordinating all sources of EU financial assistance to Turkey for pre-accession and in particular on the establishment of an Accession Partnership. This framework regulation for Turkey is modelled on the regulation for the ten Central and Eastern European candidate countries. (Council Regulation (EC) No 622/98; OJ L 85, 20.3.1998, p. 1).

The first Accession Partnership will be provided for in a Council Regulation on the establishment of an Accession Partnership for Turkey. This Accession Partnership is proposed by the Commission, after consulting Turkey and on the basis of the principles, priorities, intermediate objectives and conditions decided by the Council. It takes into account the analysis in the 2000 Regular Report of the progress made by Turkey towards membership.

\section{Objectives}

The purpose of the Accession Partnership is to set out in a single framework the priority areas for further work identified in the Commission's 2000 Regular Report on the progress made by Turkey towards membership of the European Union, the financial means available to help Turkey implement these priorities and the conditions which will apply to that assistance. This Accession Partnership provides the basis for a number of policy instruments, 
which will be used to help the candidate States in their preparations for membership. It is expected that Turkey on the basis of this Accession Partnership adopts before the end of the year a National Programme for the Adoption of the Acquis. This is not an integral part of this Partnership but the priorities it contains should be compatible with it.

\section{Principles}

The main priority areas identified for each candidate State relate to its ability to take on the obligations of meeting the Copenhagen criteria which state that membership requires:

- that the candidate State has achieved stability of institutions guaranteeing democracy, the rule of law, human rights and respect for and protection of minorities;

- the existence of a functioning market economy, as well as the capacity to cope with competitive pressure and market forces within the Union;

- the ability to take on the obligations of membership, including adherence to the aims of political, economic and monetary union.

At its meeting in Madrid, the European Council stressed the need for the candidate States to adjust their administrative structures to ensure the harmonious operation of Community policies after accession. At Luxembourg, it stressed that incorporation of the acquis into legislation is necessary, but not in itself sufficient; it is necessary to ensure that it is actually applied.

At its meeting in Helsinki, the European Council reaffirmed the inclusive nature of the accession process comprising 13 candidate States within a single framework. The candidate States are participating in the accession process on an equal footing. The European Council stated that they must share the values and objectives of the European Union as set out in the Treaties. In this 
respect the European Council stressed the principle of peaceful settlement of disputes in accordance with the United Nations Charter and urged candidate States to make every effort to resolve any outstanding border disputes and other related issues. Failing this they should within a reasonable time bring the dispute to the International Court of Justice.

The European Council also concluded that it will review the situation relating to any outstanding disputes, in particular concerning the repercussions on the accession process and in order to promote their settlement through the International Court of Justice, at the latest by the end of 2004 .

Furthermore, the European Council emphasised that Turkey will benefit from a pre-accession strategy to stimulate and support its reforms including an enhanced political dialogue, with emphasis on progressing towards fulfilling the political criteria for accession with particular reference to human rights, as well as the issues referred to in paragraphs 4 and 9(a) of the Helsinki conclusions; in this spirit, the European Union encourages Turkey, together with all parties, to continue to support the UN Secretary General's efforts to bring the process, aiming at a comprehensive settlement of the Cyprus problem, to a successful conclusion.

\section{Priorities and Intermediate Objectives}

The Commission's Regular Reports have highlighted the extent of the efforts which still have to be made in certain areas by the candidate States to prepare for accession. This situation requires the definition of intermediate stages in terms of priorities, each to be accompanied by precise objectives to be set in collaboration with the States concerned, the achievement of which will condition the degree of assistance granted and the progress of the negotiations under way with some countries and the opening of new negotiations with the others. The priorities and intermediate objectives in the Accession Partnership are divided into two groups - short and medium term. Those listed under the short term have been selected on the basis that it is realistic to expect that Turkey can complete or take them substantially forward by the end of 2001 . 
The priorities listed under the medium term are expected to take more than one year to complete although work should, wherever possible, also begin on them during 2001.

The Accession Partnership indicates the priority areas for Turkey's membership preparations. Turkey will nevertheless have to address all issues identified in the Regular Report. It is also important that Turkey fulfils the commitments of legislative approximation and implementation of the acquis in accordance with the commitments made under the Association Agreement, Customs Union and related decisions of the EC-Turkey Association Council for example on the trade regime for agricultural products. It should be recalled that incorporation of the acquis into legislation is not in itself sufficient; it will also be necessary to ensure that it is actually applied to the same standards as those which apply within the Union. In all of the areas listed below there is a need for credible and effective implementation and enforcement of the acquis.

Drawing on the analysis of the Commission's Regular Report, the following short and medium term priorities and intermediate objectives have been identified for Turkey:

\subsection{Short-term (2001)}

Enhanced political dialogue and political criteria

- In accordance with the Helsinki conclusions, in the context of the political dialogue, strongly support the UN Secretary General's efforts to bring to a successful conclusion the process of finding a comprehensive settlement of the Cyprus problem, as referred to in point 9(a) of the Helsinki conclu sions.

- Strengthen legal and constitutional guarantees for the right to freedom of expression in line with article 10 of the European Convention of Human Rights. Address in that context the situation of those persons in prison sentenced for expressing non-violent opinions. 
- Strengthen legal and constitutional guarantees of the right to freedom of association and peaceful assembly and encour age development of civil society.

- Strengthen legal provisions and undertake all necessary measures to reinforce the fight against torture practices, and ensure compliance with the European Convention for the Prevention of Torture.

- Further align legal procedures concerning pre-trial detention with the provisions of the European Convention on Human Rights and with recommendations of the Committee for the Prevention of Torture.

- Strengthen opportunities for legal redress against all viola tions of human rights.

- Intensify training on human rights issues for law enforce ment officials in mutual cooperation with individual coun tries and international organisations.

- Improve the functioning and efficiency of the judiciary, including the state security court in line with international standards. Strengthen in particular training of judges and prosecutors on European Union legislation, including in the field of human rights.

- Maintain the de facto moratorium on capital punishment.

- Remove any legal provisions forbidding the use by Turkish citizens of their mother tongue in TV/radio broadcasting.

- Develop a comprehensive approach to reduce regional dis parities, and in particular to improve the situation in the South-East, with a view to enhancing economic, social and cultural opportunities for all citizens. 
Economic criteria

- ensure the implementation of the current dis-inflation and structural reform programme agreed with the IMF and the World Bank, in particular, ensure the control of public expenditure.

- proceed to the swift implementation of the financial sector reform, aiming at guaranteeing transparency and surveil lance.

- prepare a pre-accession fiscal surveillance procedure con sisting of an annual notification of fiscal positions, in line with EU procedures and the presentation of a Pre-accession Economic Programme (PEP). The PEP aims at preparing the country for accession through a comprehensive economic programme.

- proceed with agricultural reforms

- continue the privatisation of state-owned entities, taking into account the social component.

Internal market

- Intellectual and industrial property rights: continue align ment of intellectual property legislation and strengthen the fight against piracy.

- Free movement of goods: accelerate alignment of European standards, certification and conformity assessment and marking; start to reinforce existing market surveillance and conformity assessment structures with equipment and train ing; speed up work relating to specific sectors (foodstuffs, pharmaceuticals, cosmetics, textiles) and the framework leg islation transposing New and Global Approach principles and create compatible administrative infrastructure; remove technical barriers to trade. 
- Competition: adapt legislation designating the responsibility of state aid control in order to provide the basis for trans parency and regular state aid monitoring

- Public procurement: start alignment with the Community acquis, in particular by making the procurement system more transparent and accountable.

Taxation

- start the alignment of excise duties and VAT, in particular with respect of rates, scope of exempt transactions, taxable scope and the tax structure; ensure that new tax measures comply with the principles of the Code of Conduct for Business Taxation and eliminate any discriminatory measures.

Agriculture

- develop a functioning land register, animal identification systems, plant passport systems and the improvement of administrative structures in order to monitor the agricultural markets and implement environmental, structural and rural development measures.

- establish an appropriate alignment strategy for veterinary and plant health Community legislation with first priority the harmonisation of legislation to combat animal and plant dis eases and upgrade enforcement capacity, in particular of lab oratory testing, inspection arrangements and establishments.

Fisheries

- establish administrative structures to monitor the exploita tion of fisheries resources, market and structural develop ment through a resource management policy, inspection and control measures and improvement of the fishing fleet register. 


\section{Transport}

- adopt a programme for transposition of the transport acquis.

- start aligning legislation on maritime safety standards; implement and enforce safety standards.

- adopt an action plan for maritime transport on monitoring classification societies and improving the performance of the Turkish flag register.

- start strengthening maritime administration, particularly that of flag state control.

Statistics

- adopt a strategy for the further development of statistics, in particular demographic and social statistics, regional statis tics, business statistics, external trade and agricultural statis tics.

- bring the business register up to EU standards.

Employment and Social Affairs

- adopt a strategy and a detailed programme for the alignment of the acquis.

- further strengthen efforts to tackle the problem of child labour.

- ensure that the conditions are in place for an active and autonomous social dialogue, inter alia by ensuring that trade union rights are respected and by abolishing restrictive provisions on trade union activities.

- $\quad$ support social partners' capacity-building efforts to develop and implement the acquis. 


\section{Energy}

- put in place a programme for the adoption of the EU energy acquis.

- establish an independent regulatory authority for the electricity and gas sectors; grant the authority and the means to carry out its tasks effectively.

- prepare for the establishment of the internal energy market, notably the electricity and gas directives, and the opening up of the markets.

Telecommunications

- align with the EU acquis in areas of licensing, interconnec tion and universal service; further refine liberalisation needs.

- strengthen the capacity building of the independent regulatory authority i.e. reinforce its ability to implement regulations.

Regional policy and coordination of structural instruments

- prepare a NUTS classification in accordance with Community rules.

- adopt a strategy for the development of an effective regional policy.

- start introducing regional policy criteria in the selection of projects in Turkey's planning process.

Culture and Audio-visual Policy

- start alignment of legíslation in the field of audio-visual policy, in particular with regard to the Television without Frontier Directive. 


\section{Environment}

- adopt a detailed directive-specific transposition programme of the acquis.

- transpose the Environmental Impact Assessment Directive.

- develop a plan for financing investments (directive specific), based on estimations of costs of alignment and realistic sources of public and private finance year-by-year.

Justice and home affairs

- develop information and awareness programmes on the legislation and practices in the European Union in the field of JHA.

- enhance the fight against organised crime, drugs trafficking and corruption and strengthen capacities to deal with money laundering.

\section{Customs}

- continue aligning legislation on free zones and ensure enforcement of the new Customs Code and its implementing provisions.

Reinforcement of administrative and judicial capacity

- improve the capacity of public administration to adopt, to implement and to manage the acquis in particular through training and appropriate coordination between ministries, including the development of effective border control to prevent illegal immigration and illegal trafficking in human beings and drugs.

- accelerate the modernisation of public administration includ ing strengthening the relevant administrative institutions. 
- strengthen the financial control functions, improve the efficiency of the customs and modernise the tax administration and increase the anti-fraud capacity; reinforce veterinary and phytosanitary controls also at borders restructure and upgrade food control administration,improve operation of the judicial system and further promote training for the judiciary in Community law and its application.

- adopt the legal, administrative and budgetary framework (audit manual and audit trail) for programme management.

\subsection{Medium-term}

Enhanced political dialogue and political criteria

- In accordance with the Helsinki conclusions, in the context of the political dialogue, under the principle of peaceful settlement of disputes in accordance with the UN Charter, make every effort to resolve any outstanding border disputes and other related issues, as referred to in point 4 of the Helsinki conclusions.

- Guarantee full enjoyment by all individuals without any discrimination and irrespective of their language, race, colour, sex, political opinion, philosophical belief or religion of all human rights and fundamental freedoms. Further develop conditions for the enjoyment of freedom of thought, con science and religion.

- Review of the Turkish Constitution and other relevant legislation with a view to guaranteeing rights and freedoms of all Turkish citizens as set forth in the European Convention for the Protection of Human Rights; ensure the implementation of such legal reforms and conformity with practices in EU Member States. 
- Abolish the death penalty, sign and ratify Protocol No 6 of the European Convention of Human Rights.

- $\quad$ Ratify the International Covenant on Civil and Political Rights and its optional protocol and the International Covenant on Economic, Social and Cultural Rights.

- Adjust detention conditions in prisons to bring them into line with the UN Standard Minimum Rules for the Treatment of Prisoners and other international norms.

- $\quad$ Align the constitutional role of the National Security Council as an advisory body to the government in accordance with the practice of EU Member States.

- Lift the remaining state of emergency in the South-East.

- Ensure cultural diversity and guarantee cultural rights for all citizens irrespective of their origin. Any legal provisions preventing the enjoyment of these rights should be abolished, including in the field of education.

Economic criteria

- complete the process of privatisation.

- complete the reform of the agricultural and financial sector.

- ensure the sustainability of the pension and the social security system.

- ensure the improvement of the general level of education and health, paying particular attention to the younger generation and disadvantaged regions.

Internal market

- Free movement of goods: complete alignment with the EU 
acquis; complete alignment of European standards; complete strengthening of existing certification, market surveillance and conformity assessment structures.

- Company law: complete alignment with the EU acquis.

- Data protection: complete alignment and implement legisla tion.

- Free movement of capital: complete alignment in particular by removing restrictions for foreign investors.

- Competition: complete alignment with EU acquis concerning state aids including regional aid schemes and align legislation concerning monopolies and companies benefiting from special rights.

- Public procurement: complete alignment with the Community acquis; ensure effective implementation and enforcement.

Taxation

- complete alignment of national legislation with the EU acquis.

\section{Agriculture}

- complete preparations for the acquis in agricultural and rural development policies.

- modernise food processing establishments (meat, dairy processing plants) to meet EU hygiene and public health stan dards and further establishment of testing and diagnostic facilities.

Fisheries 
- complete the development of the capacity to implement and enforce the common fisheries policy.

- continue to improve the overall quality standards and safety of fishery products in Turkey.

Transport

- complete alignment on road transport legislation (market access, road safety, rules for dangerous goods and taxation), railways, air transport (particularly air safety and air traffic management) and inland waterways (technical requirements for vessels).

- ensure effective implementation and enforcement of transport legislation, particularly that of maritime safety.

- prepare the Turkish transport fleet (particularly maritime and road transport) for the technical norms that will allow a complete integration into the Internal Market.

Economic and Monetary Union

- modify the law on the Central Bank in order to allow participation in the European System of Central Banks (ESCB).

- complete the independence of the Central Bank from the government.

\section{Statistics}

- adopt EU compatible statistical methodologies and practices, in particular as regards GDP estimation, harmonised consumer price indexes, short-term indicators, social statistics, business register and balance of payments. 
- align macro-economic statistics further with the statistical acquis.

- ensure adequate training of staff and improve the administrative capacity.

Employment and social affairs

- remove remaining forms of discrimination against women and all forms of discrimination on the grounds of sex, racial or ethnic origin, religion or belief, disability, age or sexual orientation.

- transpose EU legislation in the fields of labour law, equality of treatment between women and men, occupational healthand safety and public health, reinforce related administrative structures and those required for the coordination of social security.

- ensure effective implementation and enforcement of the social policy and employment acquis.

- prepare a national employment strategy with a view to later participation in the European Employment Strategy including through the launch of a joint employment review, and in this context, develop a capacity to monitor labour market and social developments, in particular the impact of ongoing and accelerating structural change.

- further develop social protection, notably by consolidating the reform of the social security system with a view to making it financially sustainable, while strengthening the social safety net.

\section{Energy}

- restructure energy utilities and open up further the various sectors; strengthen administrative and regulatory structures. 
- complete alignment of national legislation with the EU energy acquis.

Telecommunications

- complete the transposition of Community legislation.

- develop a comprehensive policy for the entire communications sector.

Regional policy and coordination of structural instruments

- develop a national policy for economic and social cohesion with a view to diminishing internal disparities including pluri-annual budgeting procedures and establishing structures for monitoring appraisal and evaluation.

Culture and Audio-visual policy

- complete alignment of audio-visual legislation and strengthen the capabilities of the independent television/radio regulatory authority.

Environment

- implementation and enforcement of the EU environmental acquis in particular through the development of framework and sector legislation, together with the strengthening of the institutional, administrative and monitoring capacity to ensure environmental protection.

- implement the acquis with particular attention to the framework legislation, the horizontal legislation, and to the legilation on nature protection, on water quality and on waste management; implement a waste management strategy.

- establish monitoring networks and permit procedures as well 
as environmental inspectorates, including data collection.

- integrate sustainable development principles into the definition and implementation of all other sectoral policies.

- implement and enforce the Environmental Impact Assessment Directive.

\section{Customs}

- complete alignment of legislation in particular on free zones, dual use goods and technologies, precursors and counterfeited and pirated goods.

Justice and home affairs

- develop training programmes on Community Law and on the implementation of the JHA Acquis.

- further develop and strengthen JHA institutions with a view in particular to ensuring the accountability of the police.

- adopt the EU acquis in the field of data protection so as to be able to fully participate in the Schengen Information System and in Europol.

- start alignment of visa legislation and practice with those of the EU.

- adopt and implement the EU Acquis and practices on migration (admission, readmission, expulsion)so as to prevent illegal migrations.

- continue strengthening border management and prepare for full implementation of the Schengen Convention.

- lift the geographical reservation to the 1951 Geneva Convention in the field of asylum and develop 
accommodation facilities and social support for refugees.

- adopt and implement the acquis of the EU in the field of corruption, fight against drugs, organised crime, money laundering and judicial cooperation in criminal and civil matters; further intensify international cooperation in those fields.

Reinforcement of administrative and judicial capacity

- complete public administration modernisation reform to ensure efficient management of EC policies, including strengthening border management and preparation of full implementation of the Schengen Convention.

- complete the legislative framework for internal and external financial control; complete the setting up of a central organisation within the government for harmonising internal audit/control functions; complete the setting up of internal audit/control units in spending centres; finalise "functional independence" for national internal controllers/auditors at both central and decentralised levels and "ex-ante" financial control; issue an audit manual and develop audit trial for control of EU funds.

- complete territorial reform and develop the concept of regional and municipal management.

- $\quad$ set up operational structures at regional level and reinforce existing administrative structures dealing with regional development.

\section{Programming}

During the period 1996-1999, Turkey received EUR 376 million grant aid which represents an annual average of just over EUR 90 million. From 2000 onwards the yearly allocation to Turkey has been set at $15 \%$ of the Meda bilateral envelop in addition to the 
funds foreseen in the framework of the two "European strategy/ pre-accession strategy" regulations. The first regulation, adopted in April 2000, foresees EUR 5 million a year during 3 years in order to implement measures to intensify the EC-Turkey Customs union. The second regulation, in the process of adoption, relates to the implementation of measures to promote economic and social development in Turkey, and will provide EUR 45 million/year during 3 years.

All these funds will be pre-accession orientated. In 2000 the repartition is as follows:

- $\quad 50 \%$ of appropriations will be dedicated for structural and sector reforms aiming in particular to harmonise Turkish legislation and practices with the EU acquis. Reforms will be supported through structural adjustment facilities; the objective is to help Turkey under take major structural reforms in line with the "acquis communautaire" and in close coordination with the IMF and the World Bank.

- $\quad 50 \%$ of appropriations will finance other measures aiming at Turkey's integration into the EU: to help the Turkish administration and institutions to develop the capacity to implement the Community acquis (thr ough institution building); to help Turkey to mobilise the investment needed to bring its industry and infrastructure up to Community standard (through investment support and regional/rural development). Under this allocation, Turkey can also fund part of its participation in Community programmes and agencies including in the Fifth Research and Technical Development Framework Programme (OJ L 26, 1.2.1999, p. 1) and in the areas of Education and SMEs.

\subsection{Role of International Financial Institutions}

Cooperation between Turkey and the International Financial Institutions is receiving an impetus and a new focus through the Accession Partnership. The grant resources made available under the Accession Partnership serve as seed money and a catalyst for 
larger amounts of development finance from the IFIs. This process is developed by the Commission in liaison with the candidate countries, the EIB and the IFIs, in particular the World Bank with a view to facilitating the co-financing of projects relating to pre-accession priorities. At the same time, it is important that close cooperation takes place with the programmes of other donors (Member States; third countries).

\section{Conditionality}

Community assistance for financing projects through the pre-accesion instruments for Turkey is conditional on respect by Turkey of its commitments under the Association Agreement, Customs Union and related decisions of the EC-Turkey Association Council, for example on the trade regime for agricultural products. Further steps towards satisfying the Copenhagen criteria and in particular progress in meeting the specific priorities of this Accession Partnership in 2001 need to be taken. Failure to respect these general conditions could lead to a decision by the Council on the suspension of financial assistance on the basis of Article 4 of the proposed single-framework regulation.

\section{Monitoring}

The implementation of the Accession Partnership will be monitored in the framework of the Association Agreement. As underlined by the European Council in Helsinki, for Turkey it is important that the institutions of the Association Agreement continue to be the framework within which the adoption of the acquis can be examined, in accordance with the same arrangements, irrespective of whether or not negotiations have been opened.

The relevant sections of the Accession Partnership will be discussed in the appropriate sub-committee. The Association Committee discusses overall developments, progress and problems in meeting its priorities and intermediate objectives as well as more specific issues referred to it from the sub-committees. 
To begin with, the Meda Management Committee ensures that financing decisions under the three instruments (Meda; two financial regulations under the European Strategy) are compatible with each other as well as with the Accession Partnership.

The Commission is preparing a new single regulation for the implementation of the new budget line "pre-accession strategy for Turkey" (PDB 2001). After the adoption of that regulation, the Phare Management Committee is to ensure the task of monitoring the compatibility with the Accession Partnership. 